\title{
ATHOL MAYHEW'S TRAVELOGUE “MONTENEGRO AS WE SAW IT" AS A LITERARY CULTURAL POSTCARD OF MONTENEGRO
}

\author{
Ana Pejović
}

\begin{abstract}
In this paper we shall depict an imaginary journey through Athol Mayhew's Montenegrin chronotope. More precisely, we shall present heterotopia as an associative space of evocative elements by which the author, apart from spatial and temporal, also provides a mimetic paradigm of an unfolding story.

We shall describe the ways Athol Mayhew's travel narrative "Montenegro As We Saw It" achieves its cultural and historical coding through emphasizing its intellectual, monologic, associative, essayistic, existential and dramatic mimetic paradigm.
\end{abstract}

Keywords: travelogue, Montenegrin chronotope, cultural and historical coding, Cetinje 


\section{INTRODUCTION}

Athol Mayhew's travelogue „Montenegro as We Saw It“ represents an intimate documentary discourse in which poetic and symbolic codes accomplish a multifunctional dimension based on experience, more precisely on experience which widens the boundaries of what has already been seen, "i.e. of the reality which through language enters the travelogue not as a new form of reality, but as a form of an experienced reality." (V. Brešić, 1997). The original travelogue titled "Montenegro as We Saw It" was first published in the 20th volume of the illustrated magazine Scribner's Monthly, New York, Vol XX, May 1880 - Oct 1880 Inclusive1880, p. 276-293 (Publisher: Scribner \& Co, No.743 Broadway [Editor: J.G. Holland]).

Although travelogue as a non-fictional narrative form in the history of literature and literary criticism has long held the qualification of a marginal literary genre, its role as a comparative study of literature as well as cultural and tourist mapping has never been negligible. The genesis of travelogue can be traced back from antique sources, (Platon 2002) so in this respect a travel writer himself has become a very important medium. The concept of journey, which Antun Gustav Matos calls the poetry of modern civilization, (Matos 1988) has become a kind of futuristic postcard by which the travel writer portrays his impressionistic sensations, his curiosity and cognitive novelties. He does so by focalizing from various perspectives an external, objective world of things, spaces and phenomena, often represented by the narrative process with mandatory itineraries, as well as an inner world, the expression of one's own subjectivity for which a journey is often only a pretext.

Mayhew's travelogue exists in a dichotomy of the Self which perceives and the Other which narrates. His narrative, although based on a purely monologic discourse which is the basic form of travelogue poetics, articulates certain epistemological, cultural and imaginative capital, becoming such an important synthetic element of the national literary as well as historical prose.

Having been created as a record of journeys through Montenegro and written in a harmonious mix of traditional, meditative, factographic and historical prose, travelogue, as a fundamental genre of the wider travel 
culture, sublimates elements of anthropological, political, diplomatic, touristic and ethnographic interpretation. By adopting the contemporary values of Bakhtin's theory, (Bakhtin 1989) when it comes to the genre determination of any narrative and perceiving not only Post-Structuralism but also contemporary hermeneutics and the theory of reception, we can undoubtedly confirm his argument that "double orientation" of any genre, in this case of travelogue, is one of the fundamental semantic features of a narrative text. In this travelogue, we find this "reality" of a genre in the perceived reality that the travel writer interprets to the recipient entering the real space of Montenegro, describing a real time with a precisely specified temporal pattern (October 1879). Using complex anachronies (predominantly analepses) (Marcetic 2003) the temporal plan of Mayhew's narrative discourse is being extended.

This orientation of the travelogue towards reality and its receptive focus on readers becomes one of the two members of the binary opposition which Bakhtin used to place a narrative naming it "external orientation", while the other member, the so-called "inner orientation" refers to the thematic content, to the discourse of life, events, places, problems, which have been interpreted in the travelogue by the means of the travel experience and subsequent reflection on what was seen and experienced.

\section{ATHOL MAYHEW'S TRAVELOGUE “MONTENEGRO AS WE SAW IT" AS A LITERARY CULTURAL POSTCARD OF MONTENEGRO}

Athol Mayhew begins his journey through Montenegro while he was still in England, in the isolation of the British Museum Library, in a unique blend of an overwhelming desire to learn about new places, cultures, customs, and an overheated imagination after reading the references of romantic pocket travel guides and sensational newspaper reports. “(...) Our imagination, (...) summoned a vivid picture of Montenegrin hills, covered with - oak, beech and willow forests, rocks covered with lush shrubs of strawberry trees, spruce, rosemary and myrtle trees." (Matica 2014, 253)

The inevitability of the conflict of the reality and fiction leads to the emergence of the so-called minus process which the narrator introduces 
us to, at the very beginning of the travelogue. Disappointment as a form of a failed expectation arises as soon as the narrator sets his foot on the Montenegrin soil, or more precisely, with his encounter with the visualized images of the powerful ramparts of Lovćen, an inaccessible road, the ridgelike land and the immense rocky cliffs trapped in the innumerable hills and mountains that the narrator approaches bottom-up, occupying a central position in the chronotope of a "small, stooped bridge in an arid wasteland designated for a Montenegrin market outside the walls of Kotor." (Matica 2014, 251)

Using analepse (Marcetic 2003) with a range of one year and a sixday amplitude, the narrator describes a precise temporal travel frame ("one October evening in 1879"), giving all the micro-chronological structures that, apart from semantic coding, perform a very important function of chronological perceptual orientation, which, at the paradigmatic level of the narrative, represents a unique element of cultural and touristic mapping.

In front of us the mighty walls of Lovcen emerged from the purple haze of the valley, and stood before us, dipped into the deep azure sky. Following the oscillating movement of our host's index finger along the mountain, we followed the zigzag signs of the track that swivels like a thin white cord toward the wide chest of the mountain. During our six-day trip from Arhiduchesse Charlotte, along the Dalmatian coast from Trieste to Kotor, we listened a lot about how difficult it is to travel through Montenegro. (Matica 2014, 252)

The travel writer interprets a detailed description of the arrival in Kotor in the chronologically structured series of events, describing both external and internal difficulties with which the narrating character and his friend, Dick, met. The degree of their disappointment is shown through gradationally shaped motifs of the snow covered tent, the "scary image of two unhappy passengers trapped in a sublime quarry who must mine the stone to make holes in the rocks in order to put tent pins in them" (Matica 2014, 254) and the cruel conditions of survival where their nutrition is based on raw food for the lack of "shrubs" they could put on fire in order to „use the magical cooking appliance.“" (Matica 2014, 254). The description 
of an unplanned four-day stay in Kotor is filled with motifs with a negative symbolism, so the narrator, in this part of the travelogue, breaks down the stereotypical image of moral and benevolent Montenegrins who, having heard that the two foreigners need to rent a horse and a donkey, increased their prices enormously, calling them "wild and harsh hounds from the Black Mountain."

It soon got noised about Cattaro-for rumor travels with telephonic rapidity in a town covering about the same area as we should devote to a block of alms-houses - that two adventurous spirits were anxious to hire saddle and pack horses to transport themselves and their effects over the Lovcen to Cetinje, the capital of Montenegro. This news caused great excitement in the Montenegrin bazaar, anything on four legs and bearing even the most distant resemblance to horse-flesh being immediately quoted in the market at a price equal to a native prince's ransom. It was several days before the wild, untutored drovers of the Black Mountain could be brought to moderate their demands. (Matica 2014, 254, 255)

The images of disintegration of the moral tradition of Montenegrins are interpreted in another episode in which two completely harmless strangers, looking for adventure and enjoying life in nature, became victims of robbery upon their arrival in Podgorica. In this episode of the travelogue, by using the motif of robbery and the antithetical image of the Montenegrin moral dignity, the narrator has succeeded to inform the recipient that the authorities in Montenegro severely punished this kind of offenses. Using the elements of external and internal characterization, he formed the character of Duke Plamenac, the Minister of War, who by issuing an arrest warrant, managed to convict and punish the offenders in a short period of time.

On waking in the morning we found ourselves relieved of a quarter of sheep, a saddle-bag containing a silver tobacco- case, a knife and fork, and a bag of tobacco. The affair made quite a commotion in Podgoritza, and the Minister of War, who was in residence at the quaint little war-office by the bazaar, was fearfully indignant on hearing of this outrage upon strangers, the more particularly, perhaps, because, at an interview we 
had with him before starting on our camping expedition, he was most impressive in his assurances of the Montenegrin regard for the sanctity of property. Thanks to the rapidity with which the Voivode Plamenaz put a couple of men and a sergeant, accompanied by a singularly intelligent dog, on the track of the thieves, they were captured before the afternoon, and everything was restored to us save the mutton, which the robbers-who were none other than the young gluttons whom we had entertained the previous day $-^{\wedge}$ had eaten raw. They were taken to Podgoritza, where each received twentyfive stripes with the bastinado and a short term of imprisonment. (Matica, 2014, 270)

Apart from the interpretation of these unfortunate events, the narrator complements the travelogue postcard of Montenegro by adding some historical, cultural and political information whose authenticity has been confirmed by the true history facts which form the basis of the Montenegrin national identity. The narrator shapes the images of climbing up the dangerous hillsides of Kotor with realistic images of narrow trails and by using frequent metalepsical images to address the reader conveying him only a small part of the various emotional states of an escapade which a person without any previous experience embarked on. His state was aggravated by the feeling of fear and nervousness that followed him throughout his journey across Lovcen which was at the time the only possible way to get from Kotor to Cetinje and vice versa.

The motif of the fortress St. Ivan, which rises 260 meters above Kotor, has been utilized by the writer to arouse the reader's interest by inserting retrospective narrative elements that explicitly describe the origin and fate of the main city fortress commonly known as San Giovanni fortress. By using the temporal figure of analepse, whose span is six decades with the amplitude of just a few minutes, the narrator gives the exact historical data that closely reflect the changes of centuries and various armies which conquered the fortress:

At the turn of 1813, the Fortress of St. Ivan, after having suffered the usual changes in the fate of the Dalmatian coast, and belonging to the Turks and Venetians, Austrians and the Russians, was taken over from Frenchman by the Englishman 
under the command of Hoste, who for his extraordinary skills in conveying heavy artillery along this majestic mountain received the most compliments from the French commander who has previously expressed the view that it is impossible to establish a battery in such mountains. (Matica 2014, 257).

The narrator in the travelogue molds the fictional image of the road leading from Kotor to Cetinje using a very striking psychological point of view through which perceptual field the motifs of fear, amazement, enchantment, uncertainty, freedom and relief shift successively. In this part of the travelogue, the narrator used the metalepsical discourse to give the SCRIBNER's reader a more picturesque description of the "the marvellous barriers that nature has built between the Slovenian highlanders and the sources from which they deliver supplies" (Matica 2014, 258), but also to emphasize the great strength of the Montenegrins whom the rough life and inhospitable terrain made so sturdy, almost fantastic creatures.

I have neither space nor inclination to dwell upon the tortures of the last stage of our clamber; suffice it that our progress can only be described as a rapid and varied succession of such staggers, lurches, plunges, and recoveries as might accompany a 'prentice hand upon the tight-rope; and that when we did ultimately throw our dislocated anatomies upon the top of Lowcen, it was only to realize those aches and pains which are said to follow a liberal use of the rack and bastinado. (...) There is consolation in companionable misery: instinctively we turned to solace ourselves with a study of the anguish of our guide. He was sitting composedly on a rock, eating chunks of goats' cheese and maize-bread, without a bead upon his brow or a flutter in his respiration. (...)Up the track we had just ascended, packanimals alone can be used to transport goods. But as horse-flesh is scarce since the war, and serviceable only to carry such small commodities as can be slung panier-fashion to a pack-saddle, the bulkier necessaries of life, together with the more ponderous articles of merchandise, have all to be brought from the sea into the principality upon the shoulders of the mountaineers. Many men, carrying live sheep around their necks, like big woolly comforters, or heavily laden with packing-cases on their backs. (Matica 2014, 258) 
The female characters are shaped through the chronotope of the road that, according to Bakhtin, is particularly suitable for displaying of the coincidental events. It is precisely the random encounter of the women carrying the burdens ("each with a heavy bag of corn flour bound with belts on their back.") (Matica 2014, 258) that provides the writer with an opportunity to observe, or better yet, to compare his own strength with the strength of these overloaded but courageous heroines who were passing by them with their quick and silent steps. The female characters belong to the actant type, and the narrator also uses some elements of folklore for their modelling, describing the typical Montenegrin woman by using both ideological and psychological point of view:

Even as we sat resting and fanning our flushed faces in the cool highland air, a train of stalwart, bigboned, broad-hipped women, clad in their mournful-looking black-and-white garments, and singing a strange, monotonous chant, came up from below, each with a heavy sack of maize-flour strapped upon her back. Yet there was not the slightest trace of moisture on their broad brown faces, nor a quaver in a single voice to show that they were fatigued or overburdened. (Matica 2014, 259)

The narrator depicts the character of the beautiful Montenegrin woman Emily Kovic by the successive usage of psychological, ideological and phraseological (Uspensky 1979) perspectives implemented through the double perception, i.e. through the eyes of the narrator as well as through Dick's eyes, with ethnographic motifs offering the narrator an opportunity to give the recipient more detailed and more realistic description of the typical beauty of a Montenegrin girl dressed in traditional clothes (Mrvaljevic 2006) - a type of the so-called festive costume that at that time was a real fortune.

Dick became very active and expert in model-catching, and even overcame the maiden coyness of one of the prettiest girls in the place-the black-eyed Emily Kovic, who stood to him for a sketch. And a pretty picture the little "highland lassie" made as she leaned against her cottage wall, dressed in her delicate white sleeveless coat and green goldembroidered waistcoat, open at the bosom so as to show the dainty golden-edged shirt 
confined by a single button at the throat. The white woollen coat, or gunj, and the kappa, or cap, are two articles of the national costume worn alike by both sexes, with the distinction only that with females the coat is made sleeveless and of a finer quality of cloth, ornamented at the skirts with gold embroidery, and that a black cashmere veil is attached to the crown of the kappa, and so arranged as to fall down at the back of the head. (Matica, 2014, 270)

The extremely high prices of formal male and female costumes, which became almost obligatory for the Montenegrins, caused the majority of the poor, but very proud and self-sufficient population, to sacrifice a lot and to invest significant amounts of time and energy to buy them. The money that was needed to buy beautiful and rich male or female clothes was sufficient for buying a modest Montenegrin property, so for the purpose of preserving the material and moral integrity of the Montenegrins, Prince Nikola issued orders on several occasions prohibiting the production and purchase of expensive national costumes. (Collection of court codes, commands and international agreements by the judicial profession for the Kingdom of Montenegro 1912, 126). These prohibitions were only partially implemented because of the mentality of individuality, self-complacency and excessive need for distinction that are characteristic of the bold and brave Montenegrin people.

The symbolism of the Montenegrin cap, which Mayhew describes as "the most peculiar part of the Montenegrin dress" and for which he wisely observes that it is rarely removed from the head either indoors or out, represents a highly important identity code of the moral tradition of the Montenegrin ethos, and in that respect the narrator also uses the mythological motif, symbolically connected to its origin, to give more reliable and more truthful representation of the motif of the Montenegrin cap.

The cap is, perhaps, the most peculiar part of the Montenegrin dress. By the men it is rarely removed from the head either indoors or out. In shape it is like a large forage-cap, with a black-silk edge and a crimson-cloth crown. On the rim of the crown is embroidered, in gold thread, a small semicircle, closing either the arms of Montenegro or the initials of the Prince. With 
this quaint head-covering is associated a legend which says that, when the Serbs were conquered, each member of the race placed a mourning-band around the edge of his fez, but that the Montenegrins added the half of a small golden disk to the edge of the uncovered portion of the cloth, to mark their own bright spot of freedom on the blood-red field. (Matica 2014, 270,271)

The Montenegrin cap has represented an object of particular respect throughout the centuries:

The cap was removed as a gesture of greeting and respect and only in rare occasions. (...) The stealing of the cap or removing it from a dead man's head was one of the proofs of its importance, because to offend the cap meant to offend one's honour. The courts often had to make decisions in legal cases of taking or stealing of the cap. (Mrvaljevic 2006, 72)

Every person strives to express themselves in a sociocultural environment in an adequate way. One of the ways of self-assertion and self-expression is one's own appearance, or rather the clothes through which this person is being confirmed. Alan Carter states that the nature of clothing is very complex, and that formal clothes represent many things at once. They are our social shell. They are a system of signals through which we broadcast our intentions. Formal clothes are our weapon, our challenge, our wild assault. (Carter 1977, 30)

During the Turkish rule lasting more than 300 years, the impoverished Montenegrin people dressed very scarcely. There often wore Turkish clothes which were seized or put on voluntarily, following the Turkish rules prescribing the way common people were to dress. Only during the reign of Peter I and in the period of consolidation of the state, and even in the period of economic recovery, the Montenegrins were increasingly attentive to their national costumes. (Mrvaljevic 2006, 56)

After The Congress of Berlin in 1878, when Montenegro became an internationally recognized state, there was a considerable demand for nice clothes and a desire to possess Montenegrin national costumes that was being put forward even by some Muslims and Albanians. "The tradition of the Crnojevic brotherhood was overwhelmingly present 
in the later history and awareness of the Montenegrins, so the national costumes they had created when they had been powerful and rich became the national costumes of the Montenegrins, despite their price. At the same time it became a significant symbol of self-identification, homogenization and a successful long-lasting fight for freedom of the Montenegrin people. This costume could shine again on Njegoš, as it had glittered on Djuradj Crnojevic, "in the Venetian trenches" for 350 years." (Mrvaljevic 2006, 61)

Using the associative binding of a series of ethnographic, anthropological, psychological and ethical motifs, the narrator creates a very impressive image of a Montenegrin - a loyal man, a husband and a warrior, creating another iconic sign which completes the general impression of courage and dignity of the inhabitants of this inhospitable terrain. (Tomovic 2006) The elements of the external characterization of Montenegrins are skilfully incorporated in the travelogue as symbolic narrative elements that, at the syntagmatic level, accentuate the unique characters of Montenegrin fearless heroines who follow their masters (husbands) even when they go to war.

The struka, or long brown slip of a shawl worn over the shoulders as a German student carries his plaid, is another characteristic portion of male attire, almost as indispensable to the comfort of the mountaineer as his opankes, or soft, pliable, sundried skin slippers, so curiously attached to his feet by a net-work of string running from the toe to the instep. As long as a Montenegrin has his struka, in which he can roll himself, he is perfectly indifferent as to whether his sleeping-place is the hard mud floor of some smoky way-side khan or the harder bed of his native rocks. It is his sole baggage in a campaign, where it serves him in lieu of a tent; for the rugged character of his country forces him to march in the lightest of marching order, unhampered by knapsack or haversack, relying on the women, who follow to battle on the heels of their warrior lords, to replenish his cartridge- belt and supply him with rations. (Matica 2014, 272)

The „exhibiting spotlight” in this travelogue tells us about numerous events and people, and while doing so it takes both outer and inner perspectives, thus becoming a "psychological spotlight" whose awareness reflects the fates and lives of many characters who exist in 
the reality of the travelogue. From the author's perspective, the recipient examines and makes judgments about characters that, at the level of the travelogue discourse, are being formed by the author's ideological, spatial, temporal and phraseological perspectives. The description of the Montenegrin army, of its magnitude, highly distinguished ethical dimension of the Montenegrin warrior, military ranks and the uniqueness of the Montenegrin military organization is interpreted through the perspective of the "omniscient narrator". In such a way, a new compositional node in the paradigmatic field of the narrative has been opened, including the motifs of social organizations of the Slavs, their blood relations, the origin of Montenegrin surnames, the survival in the monotonous times of peace which are very boring and insignificant for Montenegrins. (Tomovic 1976) The life of a Montenegrin was measured by his contribution and participation in the war, and not by any other useful kind of work, so the author aptly observes:

The Montenegrin is a fighting man or he is nothing, never having been taught any peaceable pursuits, and reared as he has been from childhood only to the use of arms. In peace as in war, his girdle is full of silver-ornamented artillery and decorated offensive cutlery. He is a walking magazine of murderous weapons. Under his red-morocco pouch, or kolan, lurks the long, heavy, six-chambered "Gasser" revolver, with a barrel a foot in length, and capable, when used over the left arm by way of a rest, of bringing down a man at five hundred yards. By the side of this miniature Gatlin, and ready to hand, stuck crosswise through the silken waists as his an ivory-hilted yataghan -an ugly serpentine weapon as long and heavy as a sword-bayonet, and as formidable in their practiced hands Goorkha's kookree ; while over his shoulder is slung his dobro po'uska-an Austrian "Wenzel " breechloader, or a Turkish Peabody-Martini rifle. (Matica 2014, 266)

Visual perception of the world (various spatial forms, visible objects) in a literary work (in this case, a travelogue) implies a certain perception of linguistic models (Lotman 1976, 287) which are characterized by an iconic principle - the obviousness. The spatial structure of Meyhew's travelogue "Montenegro as we saw it" sublimates many elements of 
thematised narrative forms and features that become semantic equivalents of the all that is presented, so in this respect we can speak of various "spatial categories" in this travelogue. The category of "space in space" in this narrative is Cetinje which the author shapes as a chronotope that carries out its significance through numerous psychologically distinct characters whose fates form a special layer of the travelogue discourse and a very important binary opposition of physical and metaphysical space.

The narrator forms the chronotope of Cetinje using a series of motifs whose semantics corresponds with the subtle, positive emotions that the narrator tells us about ("We returned to Cetinje and soon we felt as if we were at home in a small capital, and most of all because most of the visitors of Vuk Vuletić spoke German"). Apart from psychological, he uses ideological and phraseological perspectives. The image of Cetinje represents the central chronotopic structure of the travelogue because of the author's thought-based upgrading of the so-called digression whose semantic nucleus is shaped by a series of micro-chronotopic units that the narrator presents to the recipient. In the smaller textual parts of the travelogue, there is a description of Vuk Vuletić hotel, his famous cafe as a gathering place of the majority of male inhabitants of the capital, and them having fun by playing cards or billiards ("Here, in the evening, after a common dinner at the host table, we can attend the unusual spectacle of the family confederation ", composed of the postman, His Excellency Minister of Finance, waiter, secretary general and Mr. Vuk Vuletic, all involved in the social game of billiards! And indeed, the great Republican principles of freedom, equality and fraternity could not be put to a more serious test than this") (Matica 2014, 273); The prison for which the author claims to be the most striking building of its kind in Europe ("The fact is, something more like a livestock breach than a prison, since only four stone walls were built, about eight feet high, without roof, mostly wide open space, because the doors are removed from the hinges. In Montenegro, a criminal is his own prisoner. He is a very simple and submissive type of man who, when he commits a criminal offense, expiates in the most appropriate way by going straight to jail, stubbornly refusing to leave until his sentence expires") (Matica 2014, 274); Senate - the greatest legislative body is described by the author through a metaphorical-comparative 
image: "If Cetinje is the smallest capital in the world, then the meeting place of the Senate is undoubtedly the largest on the planet, because it is held under the open sky, below the famous elm, in the centre of the capital. The law is in the hands of the Senate of sixteen members elected for a year by all men who are carried weapons - by voting, which is reduced to the right to vote among this warlike race, in which readiness for the army is calculated from the year of twelve, while the obligation to execute a military duty counts from seventeen to fifty years old. "(Matica 2014, 275); The reading room where the author uses the analepse with the range of almost five centuries in order to give the recipient more detailed and more precise explanation of the importance of establishing the first Montenegrin printing house, the powerful enlightening and literary influence that it had, not only on the Montenegrin but also on European society: "And despite everything, the thing which serves Montenegro for honour and glory is not a legend, but it is precisely the fact that Montenegro is one of the first countries to introduce the printing press. (...) It was only seven years after Caxton printed his first volume in rich and dense populated metropolis of England, when there was no printing press in Oxford, either in Cambridge or in Edinburgh. It was only sixteen years after the establishment of the first printing press (1468) in Rome, the capital of Christianity, and only twenty-eight years (1450) after the appearance of the first printed book. Today's Montenegrins have remained faithful to their literary tradition, and the Reading Room in Cetinje has always been well-visited, and wellequipped with newspapers from all over Europe. "(Matica 2014, 277).

The writer expands his role of a chronicler with various descriptions and takes on a number of new features that allow him, by using his position of an observer with a wide spectrum of perspectives (a panoramic perspective) (... We are crossing the sterile, wavy plain leading to Njegusi, the birthplace of the ruling prince ... Only now, when we are wondering about the chaotic scenes of the Dinaric Alps, which roam on the horizon, and ridges and cliffs and irregular bumps, we could fully understand the extent of the unpromising areas of this Great Stone Earth. ") (Matica 2014, 260,261) to narrow his viewpoint by limiting it to individual clips and forming a series of episodic events in which the element of reality reaches its highest degree, i.e. becomes the key to deciphering situations in 
which the narrator appears as a witness to some events, with the inevitable consequence of complicating the temporality of the story.

An example of this is found in the episode of the encounter with the builders of the new road from Kotor to the capital, in which the narrator, first through the prolepsic discourse ("The new road for chariots through Montenegro which was planned to break with small slopes around Lovćen to Cetinje, then further to Rijeka to connect with Skadar Lake, has the destiny, once it is completed, to serve as a wonderful change in the present presentation of this country, because only then it becomes open to trade and the influence of external civilizations. ") (Matica 2014, 260) and then with the use of an analepse, thoroughly informs the reader about the time and the way of the construction of the road ("Initially, this project started in Kotor in 1872 under the leadership of Josip Slade-Silovic, an engineer from Dubrovnik. Works on the construction of the road were interrupted as soon as they reached the Montenegrin border due to the outbreak of war."). (Matica 2014, 260)

The author uses the motif of the road as an element convenient for a more detailed characterization of the character of Prince Nikola, the then ruler of Montenegro, whom the people, apart for Nikita, called "the road builder" because he vigorously insisted on the construction of roads throughout Montenegro. The ideological point of view of the narrator in this part of the travelogue is focused on the parallel (internal and external) characterization of the Prince. When forming this character, the author used numerous motifs whose semantic layers form an impressive political, literary, intellectual and historical personality. The chronotop of Petrović's palace, apart from the meeting place, becomes an important composing node of the travelogue, but also an inevitable element of an intimate shaping of the character of Prince Nikola, who is close to the type of personage, since the reader, apart from the external, physical characteristics of the character, is acquainted with his inner, psychological preoccupations.

The narrator, to whom we can assign the role of homodiegetic narrator in the travelogue (Genette 1980) forms the character of Prince Nikola by using double analepses by which he presents a very precise genealogical image of the ruling Petrović dynasty, the system of state and church regulation of the principality with all its internal and external 
political and military determinants, emphasizing the character of the Prince as a symbolic figure not only on the Montenegrin but also on the European historiographic map.

Prince Nikola is undoubtedly the most prominent figure in the country and only due to his energetic patriotism Montenegro takes a prominent place on the political map of Europe. Montenegrin demands are no longer ignored in foreign courts, and at the Berlin Congress its continuing fight against the Turks for life and freedom has been rewarded with a considerable increase in its borders. (...) Prince Nikola himself is completely available for peaceful solutions. There are more learned people around him, then soldiers. His greatest satisfactions are the schools he has built throughout the country, then his farm in Danilovgrad where he is experimenting with planting coffee, as well as his own literary aspirations. As author, Knjaz contributed to the development of literature in his country by publishing a tragedy and a collection of poems. This poetic talent, indeed, is heritable in Petrovićs house, and there is almost no huts in the country where, in the evening, we will not hear some of Prince's verses singing with a national instrument with one wire - gusle. (Matica 2014, 279)

By frequent use of the phraseological perspective, the narrator implicitly informs the readers about the fact that his knowledge of this country and its people is unquestionable, giving, at the paradigmatic level of the travelogue, the symbol of Montenegro the rank of an iconic sign.

In any language, the country is called the Black Mountain: so in Greek it is called Mavro Vuoni; Albanians call it Mal-Esija; on the Arabic map is marked as Al-jubal-al-Aswad; The Turks call it Karadagh, and the Slovenian Tzerna Gora. (Matica 2014, 261) 


\section{CONCLUSION}

Apart from the use of the retrospective technique and the first person narrative for the purpose of designing the travel reality, which is primarily based on elements of heterotopia, the travel prose of Atol Mauhew, "Montenegro as we saw it" accomplishes its cultural and historical coding through the accentuated intellectualistic, associative monologue, essayistic, existentialist and dramatic and mimetic paradigm.

In his travelogue, apart from the central thematic discourse of Montenegrin chronotop or its geographical determinations of Njeguši, Cetinje, Kotor and Podgorica, all of which represent very important symbolic and semantic micro-chronotopic elements, Athol Mayhew depicts a remarkable postcard of the late 20th century Montenegro. This document of a creative process, structured in the consciousness of a foreigner, as a dialogue between the expected, the experienced and the subsequently reflected "material of consciousness" is a very important evidence of emancipation and of realization that we all carry some universal values and virtues inside ourselves.

In this narrative, the author uses toponymic concepts for the designation of specific places to accomplish a kind of "a narrative fixation of space", i.e., he establishes a static condition by which the consciousness of the recipient binds to a certain place that has an active function in the narrative tissue - the places mentioned have become interlaced with the real narrative flow, such as: Podgorica, Njeguši, Cetinje, Rijeka Crnojevića, Kotor, but on the other hand, within these larger spatial units, there is a breakdown of the "framing" spatial fixations, since the author introduces into them a large number of smaller spatial concepts that are most often shaped by the system of binary opponency: open - closed, pleasant unpleasant, high - low, spacious - cramped, physical - metaphysical, occupied - free space. With his descriptions of the micro-chronological units of the prison, Reading room, Billiards, Lokanda (the only Montenegrin hotel managed by the famous Montenegrin merchant Vuk Vuletić), Printing house, Senate, a Montenegrin stone house with fireplace, a hut, the ruins of Diocletian's Palace, the narrator symbolically refers to the bearers of these spatial forms, providing the reader with skilfully shaped 
images of Montenegrin ethnicity. The travelogue's analytical discourse, dominated by the elements of ethnography, refers reflectively to a specific and self-contained anthropological paradigm - a culture of dressing, which on a wider scale becomes an authentic witness not only of the epic but also of the impressive aesthetic spirituality of the Montenegrins. 


\section{REFERENCES}

"Matica”, ljeto 2014. Athol Mayhew, „Montenegro as we saw it“. Crna Gora kakvu smo je mi viđeli. Preveo Radoslav Jovanović Atos.

Bahtin, M. 1989. O romanu (About the Novel). Translated by Aleksandar Badnjarević. Beograd: Nolit.

Brešić, V. 1997. Hrvatski putopisi, (Croatian Travel Books). Zagreb: DIVIČ. Carter, A. 1977. Notes for a theory of sixties style, Arts in Society, FontanaCollins.

Genette, G. 1980. Narrative Discourse Revisited. Ithaca: Cornell Universsity Press.

Lotman, Y. 1976. Stuktura umetničkog teksta (Structure of Artistic Text). Translated by Novica Petković. Beograd: Nolit.

Marčetić, A. 2003. Figure pripovedanja. Beograd: Narodna Knjiga/Alfa.

Matoš, A. G. 1988. Misli i pogledi, (Thoughts and Views). Zagreb: Globus.

Mrvaljević, Z. 2006. Crnogorska narodna nošnja, (Montenegrin National Costume). Podgorica: JU Muzeji i galerije.

Platon. 2002. Država. Translated by Vilhar A. and B. Pavlovic. Beograd: BIGZ.

Tomović, S.1976. Esej o čojstvu (Essay about humanity). Podgorica: Pobjeda. Tomović, S. 2006. Moralna tradicija Crnogoraca (Montenegrin moral tradition). Podgorica: CID.

Uspenski, B. 1979. Poetika kompozije,semiotika ikone. Beograd: Nolit.

Zbornik sudskih zakona, naredaba i medunarodnih ugovora po sudskoj struci za Kraljevinu Crnu Goru, II, (Collection of court codes, commands and international agreements by the judicial profession for the Kingdom of Montenegro) Cetinje, 1912. 
